\title{
Complicaciones de los tornillos de bloqueo intermaxilar en el tratamiento de las fracturas mandibulares
}

\author{
Complications of self-tapping bone screws for maxillomandibular fixation in \\ the treatment of jaw fracture
}

J. Molina Montes' , J. González-Lagunas², J. Mareque Bueno', J.A. Hueto Madrid², G. Raspall Martí3

Resumen: Durante la última década se ha introducido el tornillo de bloqueo intermaxilar como método de fijación maxilomandibular en el tratamiento de las fracturas de mandíbula. El propósito del estudio es evaluar las complicaciones de la técnica y la yatrogenia dental que derivan de su aplicación durante un periodo de 4 años. Se han revisado un total de 62 pacientes y 272 tornillos y, aunque han aparecido complicaciones, su incidencia es baja.

Palabras clave: Fijación intermaxilar; Fractura mandibular; Complicaciones; Fractura mandibular; Cirugía.

Recibido: 18.12 .06

Aceptado: 16.06 .08
Abstract: In the last decade, self-tapping bone screws have been used widely as a temporary maxillomandibular fixation method in the treatment of jaw fractures. The purpose of the present study was to evaluate the complications of the technique and potential dental iatrogenesis over a period of 4 years. We reviewed a total of 62 patients and 272 screws. Although complications appeared, the complication rate was low.

Key words: Maxillomandibular fixation; Jaw fracture; Complications; surgery.

1 Médico Residente

2 Médico Especialista

3 Jefe de Servicio

Servicio Cirugía Oral y Maxilofacial.

Hospital Universitario Vall d’Hebrón, Barcelona. España

\section{Correspondencia:}

Dr. Javier Gonzalez Lagunas

Hospital Universitario Vall d'Hebrón

08035 Barcelona, España

Email glagunas@terra.es 


\section{Introducción}

Las fracturas de mandíbula precisan normalmente de una fijación intermaxilar temporal con un registro correcto de oclusión para reducirlas antes de fijarlas. El método estándar ha sido durante muchos años el bloqueo intermaxilar con arcos y alambres, proporcionando al paciente discomfort y baja tolerancia, así como daño periodontal y dificultad para la higiene oral. Los tornillos de bloqueo intermaxilar han sustituido a las ligaduras alámbricas por ser un método más fácil, rápido, mejor tolerado por el paciente y con un menor riesgo de punción para el cirujano que el uso de alambres.

El objetivo de este estudio es revisar la incidencia de yatrogenia dental que producen los tornillos de bloqueo intermaxilar.

\section{Material y método}

Se revisaron los pacientes atendidos en nuestro servicio de cirugía Oral y Maxilofacial entre enero de 2002 y junio de 2006 por presentar una fractura de mandíbula. En 62 de ellos se utilizaron tornillos de bloqueo intermaxilar para proporcionar una fijación intermaxilar estable con ayuda de alambres o gomas elásticas.

De los 62 pacientes incluidos en el estudio, 52 fueron hombres (62\%) y 10 mujeres (16\%), con edades comprendidas entre los 17 y 57 años.

Los tornillos utilizados tenían una composición de acero 316L, una longitud de entre 8 y $12 \mathrm{~mm}$ de longitud, y un diámetro de $2,0 \mathrm{~mm}$, y la característica más importante es que al ser autoperforantes no necesitaban de perforación previa antes de su colocación transmucosa.

El tipo de fractura más frecuente fue la condílea/subcondilea $(30,6 \%)$ (Tabla 1).

Se instalaron un total de 272 tornillos que permanecieron en su sitio una media de 6 semanas. Su distribución fue de al menos de un tornillo por cuadrante (Fig. 1). Solamente en un caso se colocaron 3 tornillos debido a la aparicion de complicaciones técnicas durante el procedimiento quirúrgico.

Los tornillos fueron colocados por diferentes miembros del staff y por médicos residentes que se valieron de la radiografía panorámica preoperatoria como guía para la localización de las raíces dentales.

Todos los pacientes fueron tratados con antibioticoterapia postoperatoria durante 7 días. Se realizaron controles clínicos durante una media de 6 meses, con radiografias panorámicas postoperatorias y otra después de la retirada de los tornillos. También se realiza-

\section{Introduction}

Jaw fractures usually require temporary maxillomandibular fixation in correctly aligned occlusion for fracture reduction before fixation. The standard method for many years has been maxillomandibular fixation with arches and wires, which is uncomfortable and poorly tolerated by the patient. It also causes periodontal damage and makes oral hygiene difficult. The insertion of self-tapping bone screws for maxillomandibular fixation have replaced wiring the mouth shut as a quicker and easier method that is better tolerated by patients and is less likely to produce prick wounds in the surgeon than wires.

The aim of this study was to review the incidence of dental iatrogenesis produced by bone screws for maxillomandibular fixation.

\section{Material and method}

We reviewed the patients treated for jaw fracture in our maxillofacial surgery department between January 2002 and June 2006. In 62 patients, bone screws for maxillomandibular fixation were used to provide stable jaw fixation with the aid of wires or elastic bands.

Of the 62 patients enrolled in the study, 52 were men $(62 \%)$ and 10 women (16\%). Patient age range was 17 to 57 years.

The bone screws were of $316 \mathrm{~L} \mathrm{steel,} 8$ to $12 \mathrm{~mm}$ long, with a diameter of $2.0 \mathrm{~mm}$. The most important feature was that the bone screws were self-tapping did not require drilling before inserting them transmucosally.

The most frequent type of jaw fracture was condylar/subcondylar (30.6\%) (Table 1).

A total of 272 bone screws were placed and remained positioned for a mean of 6 weeks. At least one screw was positioned in each quadrant (Table 2). Three screws were placed in one patient due to technical complications during the surgical procedure.

Bone screws were placed by different staff members and medical residents who used preoperative panoramic radiography as a guide for locating dental roots.

All patients were given postoperative antibiotic therapy for 7 days. Patients were followed up clinically for a mean 
ron pruebas de vitalidad dental en dos situaciones: (a) en aquellos dientes en los que los tornillos radiográficamente parecían dañar la raíz dental o (b) cuando los dientes vecinos clínicamente presentaban sensibilidad al frío/calor.

\section{Resultados}

La complicación más frecuente encontrada fue la cobertura por mucosa oral del tornillo y se observó en 13 de los 272 tornillos colocados (4,7\%). Los tornillos se retiraron sin anestesia excepto en estos 13 pacientes, en los que se precisó la infiltración con anestesia local. No se perdió ningun tornillo pero en 5 tornillos se observó movilidad en el momento de retirarlos $(1,8 \%)$.

En el momento de la colocación de los tornillos de bloqueo se fracturaron 5 $(1,8 \%)$ a nivel de la unión de la cabeza (Figs. 2 y 3 ), todos ellos colocados por diferentes miembros del servicio y de diferentes medidad de longitud, tanto en mandibula como maxilar.

La lesión o daño radicular (definido como el contacto radiográfico entre tornillo y raiz dental) aparece en un $4.4 \%$ de los casos (Figs. 4 y 5). En 10 pacientes solo significó un rasguño en la raíz sin sintomatología clínica, con pruebas de vitalidad normal y sin movilidad del diente afecto.

En 2 pacientes $(0,8 \%)$ las pruebas de vitalidad pulpar fueron positivas, con sensibilidad dental afectada, pero solo uno de ellos necesitó de un tratamiento endodóncico en el seguimiento postoperatorio, siendo ésta la complicación más importante del estudio (Figs. 6-9).

Las molestias aparecidas en el $4,4 \%$ de los pacientes están en relación al tiempo de permanencia del tornillo en boca, siendo las más frecuente la úlcera por decúbito de la mucosa labial y el dolor residual al retirar el tornillo.

\section{Discusión}

En el tratamiento de las fracturas de mandíbula se han utilizado diferentes métodos de estabilización externa para efectuar el bloqueo intermaxilar. Hasta hace pocos años el método más común drant.

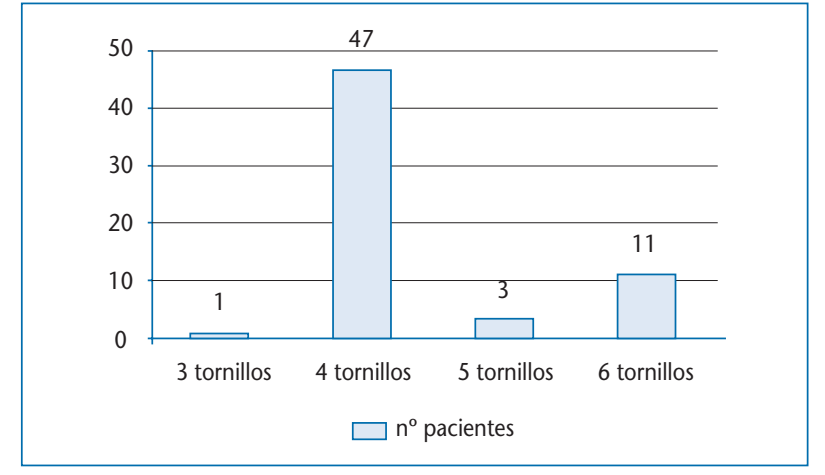

of 6 months with postoperative panoramic radiography and once more after screws were removed. Tooth viability was tested in two situations: (a) in teeth in which the screws appeared to have damaged the root on radiography and (b) when neighboring teeth presented clinical sensitivity to cold/heat.

Figura 1. Distribución pacientes $/ \mathrm{n}^{\circ}$ tornillos.

Figure 1. Distribution of patients/number of screws.

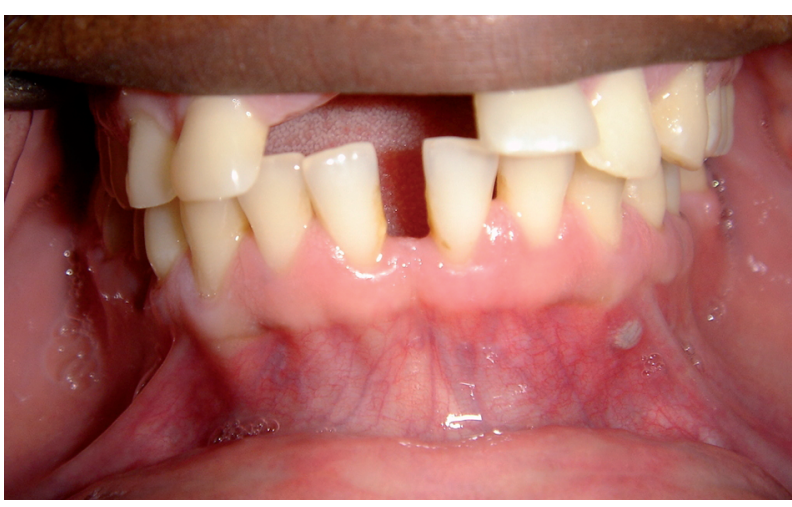

Figura 2. Imagen clínica de rotura de tornillo en 3er cuadrante. Figure 2. Clinical image of rupture of a bone screw in the third qua-

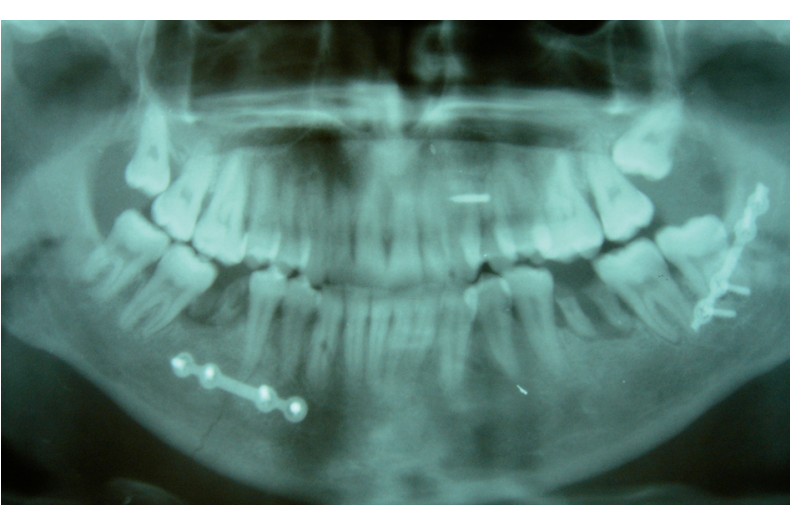

Figura 3. Imagen radiográfica de rotura de tornillo. Figure 3. Radiographic image of ruptured bone screw.

\section{Results}

The most frequent complication observed was mucosal overgrowth of the screw, which occurred in 13 of the 272 screws inserted (4.7\%). Screws were removed without anesthesia except for these 13 patients, who required infiltration of local anesthesia. None of the screws was lost but 5 screws were loose when removed (1.8\%).

When the self-tapping bone screws were inserted, 5 (1.8\%) screws fractured at the point of union between the head and shaft (Figs. 1 and 2). The screws were inserted by different members of the department, had different lengths, and were placed in both the mandible and maxilla.

Root injury (defined as radiographic evidence of contact between a screw and a dental root) occurred in $4.4 \%$ of cases (Figs. 3 and 4). In 10 patients, the screw scratched the root but did not originate clinical symptoms. Vitality tests yielded normal results and the affected tooth showed no loosening.

In 2 patients (0.8\%), pulp vitality tests were positive and dental sensitivity was affected. Only one of these teeth required root canal during the postoperative follow-up, which was the most important complication of the study (Figs. 5-8).

The discomfort that occurred in $4.4 \%$ of patients was related to the dwell time of the screw in the mouth. The most 
eran las férulas con ligaduras de alambre peridentales, pero los tornillos de fijación intermaxilar han desplazado a las citadas férulas desde que Arthur y Berardo describieron la técnica en 1989. Se han descrito muchas ventajas en comparación con el método clásico entre las que figuran su inserción fácil, la disminución del tiempo quirúrgico, una mejor higiene oral, la facilidad de retirarse sin anestesia así como la disminución del riesgo de punción del cirujano y de tranmisión de enfermedades contagiosas..$^{1-5}$ Otra característica importante es la menor lesión que se produce en la papila dental y en la mucosa oral si utilizamos tornillos en lugar de ferula. ${ }^{4,6}$

La principal desventaja de este método de bloqueo es la posibilidad de dañar a las raices dentales en el momento de inserción de los tornillos. A diferencia de otros estudios publicados, en nuestra serie no se ha utilizado un fresado previo a su colocación por ser autoperforantes, de forma que si el tornillo no es colocado entre dos raíces se nota una resistencia importante que advierte al cirujano de la necesidad de cambiar la dirección. La manera para visualizar la posición de las raíces antes de colocar-

los es evaluar la radiografía panorámica y tener precaución en los casos de apiñamientos, dientes incluidos o supernumerarios. Aunque existen numerosas radiografias en las que parece existir contacto entre el tornillo y la raíz dental, son pocos los casos en los que aparecen complicaciones, ${ }^{7}$ o que adquieren una mínima significación clínica.

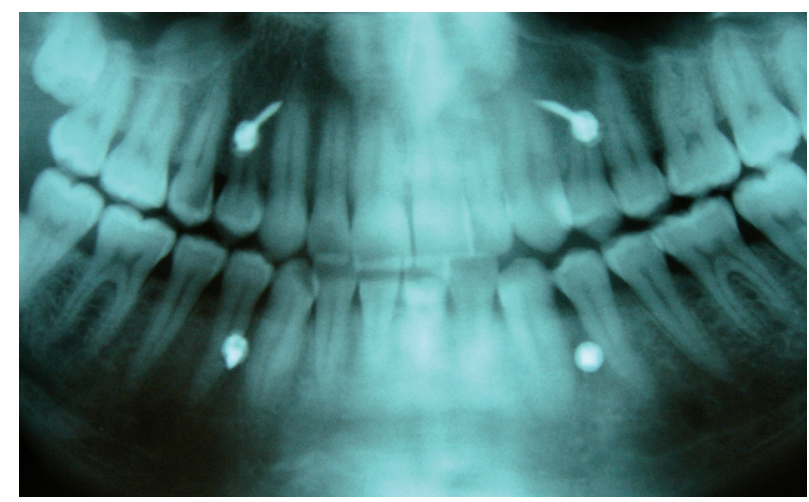

Figura 6. Tornillo en contacto con la raíz dental del 44. Figure 6. Screw in contact with dental root of 44 . frequent complication was ulceration of the labial mucosa and residual pain after the screw was removed.

\section{Discussion}

Different methods of external stabilization have been used to produce maxillomandibular fixation in the treatment of jaw fractures. Up until a few years ago, the most common method of immobilization was using splints and wire ties around the teeth. However, bone screws for maxillomandibular fixation have displaced splints described since Arthur and Berardo described the technique in 1989. Many advantages over the classic method have been described, including easy placement, shortened surgical time, better oral hygiene, ease of removal without anesthesia, and reduction of the risk of prick wounds and the attendant transmission of contagious disease to surgeons. ${ }^{1-5}$ Another important advantage is that screws make smaller wounds in the dental papilla and oral mucosa than splints. 4,6

The main disadvantage of this fixation method is that dental roots may be damaged during screw insertion. In con-

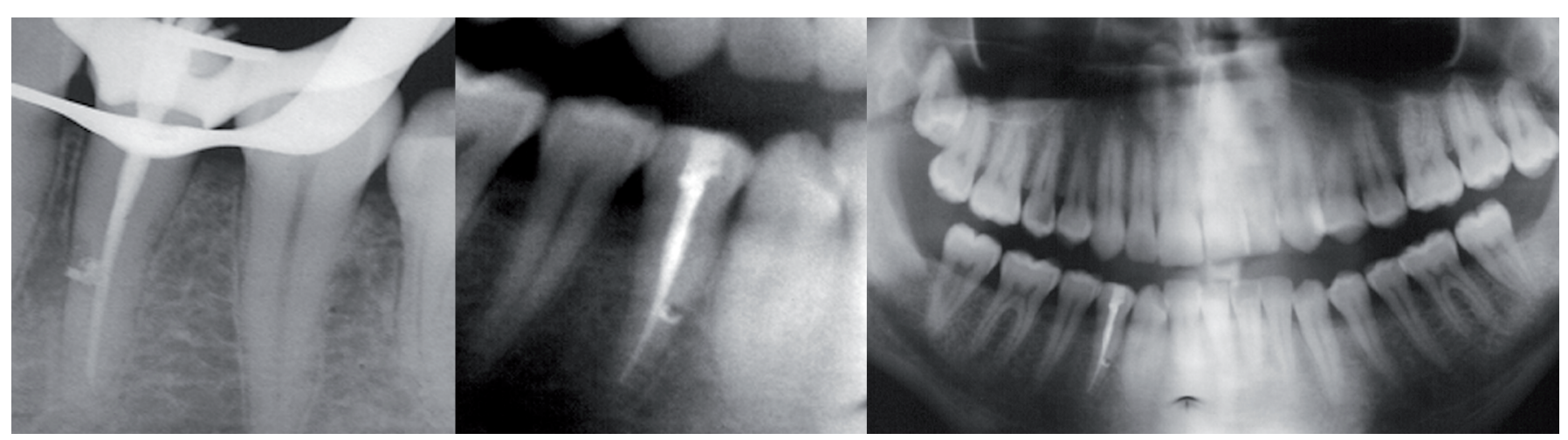

Figuras 7, 8 y 9. Endodoncia del 44 en paciente tratado de fractura subcondilea mediante BIM con tornillos y alambres. Figures 7, 8 and 9. Root canal of 44 in patient with subcondylar fracture treated by maxilloman. 
La pérdida del tornillo antes de su retirada, 2,4 la pérdida de dientes adyacentes a los tornillos y la fractura del tornillo ${ }^{8}$ son complicaciones que ya aparecen descritas en la literatura.

Colocar el tornillo entre la encía adherida y la encía móvil es la mejor manera de evitar la cobertura por mucosa oral de la cabeza del tornillo. ${ }^{4,6}$ De esta manera la retirada del mismo se puede efectuar sin anestesia.

La fijación intermaxilar con tornillos no está indicada cuando se necesita una tracción direccionable con bandas elásticas para corregir una maloclusión $\mathrm{n}^{4,8}$ ni tampoco en fracturas conminutas o en niños con erupción decidua o intermedia. ${ }^{4,7}$

\section{Conclusiones}

Los tornillos de fijación intermaxilar son una técnica alternativa y válida a la técnica clásica de fijación con férulas y alambres. Disminuye el tiempo operatorio, mejora la tolerancia del paciente, facilita la higiene oral, existe menor trauma de la papila dental y de la mucosa oral, disminuye el riesgo de punción y de transmisión de enfermedades contagiosas por parte del cirujano y como característica más importante existe un bajo índice de lesión dental (0,8\%). La destreza del cirujano es la manera más fácil de evitar complicaciones como la lesion de la raíz dental o la fractura del tornillo de fijación.

Al finalizar este estudio retrospectivo hemos observado que los pacientes que necesitaban de una tracción elástica para corregir una maloclusión postoperatoria fue mínimo. Una opción para intentar disminuir las complicaciones derivadas de la permanencia del tornillo en boca (cobertura por mucosa oral de la cabeza del tornillo, discomfort del paciente, ...) sería retirar los tornillos cuando la fractura mandibular no requiera un bloqueo postoperatorio o cuando presentan una buena reducción y estabilización del foco de fractura postquirúrgica.

\section{Bibliografía}

1. Arthur G, Berardo N. A simplified technique of maxillomandibular fixation. J Oral Maxillofac Surg 1989;47:1234.

2. Karlis V, Glickman R. An alternative to arch-bar maxillomandibular fixation. Plast Reconstr Surg 1997;99:1758-9.

3. Maurer P, Syska E, Eckert AW, Berginski M, Schubert J. The FAMI screw for temporary intermaxillary fixation. Mund Kiefer Gesichtschir 2002;6:360-2.

4. Roccia F, Tavolaccini A, Dell'acqua A, Fasolis M. An audit of mandibular fractures treated by intermaxillary fixation using intraoral cortical bone screws. I of Cranio-Maxillofac Surg 2005;33:251-4.

5. Imazawa T, Komuro Y, Inoue M, Yanai A. Mandibular fractures treated with maxillomandibular fixation screws. J Craniofac Surg 2006;17:544-9.

6. Gordon KF, Read JM, Anand VK: Results of intraoral cortical bone screw fixation technique for mandibular fractures. Otolaryngol Head Neck Surg 1995;113:248-52.

7. Fabbroni G, Aabed S, Mizen K, Starr DG: Transalveolar screws and the incidence of dental damage: a prospective study. Int J Oral Maxillofac Surg 2004;33:442-6.

8. Coburn DG, Kennedy DWG, Hodder SC. Complications with intermaxillary fixation screws in the management of fractured mandibles. Br J Oral Maxillofac Surg 2002;40:241-3. trast with other published studies, drilling was not used in our series because bone screws were self-tapping. If a selftapping screw is not positioned between two roots, the surgeon immediately notices resistance and can change direction. Root position was visualized before screw insertion by examining the panoramic radiograph. Crowding and impacted or supernumerary teeth were carefully avoided. Although there are many radiographs in which a screw seems to be in contact with the dental root, there are few instances of complications ${ }^{7}$ or of clinically relevant complications.

Screw loss before extraction, ${ }^{2,4}$ loss of teeth adjacent to screws, and screw fracture ${ }^{8}$ are complications that have been reported in the literature.

Inserting the screw between adhered gum and movable gum is the best way to prevent encroachment of the oral mucosa on the screw head. 4,6 Unencumbered screws can be removed without using anesthesia.

Maxillomandibular fixation with bone screws is not indicated when elastic band traction is needed to correct malocclusion ${ }^{4,8}$ in comminute fractures, or in children with deciduous or intermediate tooth eruption. 4,7

\section{Conclusions}

Bone screws for maxillomandibular fixation are a valid alternative to the classic fixation technique with splints and wires. This technique reduces operating time, improves patient tolerance, facilitates oral hygiene, is less traumatic to the dental papilla and oral mucosa, and diminishes the risk of accidental pricks and contagious disease transmission to surgeons. Most importantly, the rate of dental injury is low $(0.8 \%)$. The surgeon's skill is the best guarantee for avoiding complications like root injury or bone screw fracture.

At the end of this retrospective study, we observed that the number of patients who required elastic traction to correct postoperative malocclusion was minimal. One option for reducing complications derived from the presence of intraoral screws (overgrowth of the screw head by oral mucosa, patient discomfort, and other) is to remove screws when the jaw fracture does not require postoperative fixation or when the postoperative reduction and stabilization of the fracture focus is good. 